\title{
Evidence for Higher Soil Temperature and Potassium Promoting Invasion of the Common Dandelion, Taraxacum officinale, in Denali National Park and Preserve, Alaska
}

\author{
ROSEANN V. DENSMORE
}

\author{
U. S. Geological Survey, Alaska Science Center, 4210 University Drive, Anchorage, Alaska 99502 USA
}

Densmore, Roseann V. 2008. Evidence for higher soil temperature and potassium promoting invasion of the Common Dandelion, Taraxacum officinale, in Denali National Park and Reserve. Canadian Field-Naturalist 122(1): 67-69.

Common Dandelion, Taraxacum officinale ssp. officinale (dandelion) is expanding its range in Alaska and is of particular concern in National Park Service units. This study investigated the influence of estimated soil temperature, available potassium $(\mathrm{K})$, available phosphorous $(\mathrm{P})$, and total nitrogen $(\mathrm{N})$ on dandelion cover and density on a site near the elevational limit of dandelion. The study site in Denali National Park had been disturbed by construction and was revegetated with native plants 12 years before the study. Seed input to the study site was abundant. In a multiple regression analysis, higher levels of estimated soil temperature and available $\mathrm{K}$ accounted for $79 \%$ and $73 \%$ of the variation in dandelion cover and density, respectively. Practical control methods include not fertilizing disturbed areas with $\mathrm{K}$, and countering continued expansion of dandelion by monitoring human use areas and undisturbed habitats where soil temperatures are likely to be relatively warm.

Key Words: Dandelion, Taraxacum officinale, invasive plants, Denali National Park, Alaska.

Common Dandelion, Taraxacum officinale ssp. officinale (referred to hereafter as dandelion), is a common and widespread non-native plant that has spread from Europe to every continent except Antarctica. In Canada and the northern United States, dandelion is a weed in lawns and minimum till crops (Royer and Dickinson 1999; Stewart-Wade 2002). The range of this species has been expanding in Alaska (AKEPIC 2005; Hultén 1968). Dandelion is often the first invader in Alaskan National Park Service (NPS) units (McKee 2004), which have a mandate to conserve unaltered ecosystems and scenery. Alaskan national parks offer a valuable resource - millions of acres of native plant communities with no non-native plants. Dandelion invasion, in part, reflects the local effect of expanding human use accompanied by disturbance and dandelion seed input. In addition, the warming climate of Alaska, with increases in air and soil temperature and thawing of permafrost (ACIA 2005; Jorgenson et al. 2001) may be aiding dandelion expansion. Soil nutrient levels are also important in the establishment and growth of dandelion. Research in Great Britain and Minnesota has shown that the number and cover of dandelion plants in grasslands and lawns were much higher where fertilizer with potassium $(\mathrm{K})$ was added or in lawn habitats that were high in K (Tilman et al. 1999), while increased phosphorous (P) also promoted dandelion, but was not as important as $\mathrm{K}$.

The objective of this study was to evaluate the effect of soil temperature and nutrients on dandelion cover and density on a site near the range limit of dandelion in an Alaskan National Park. A primary goal was to evaluate whether revegetation methods that included seeding native legumes and fertilizing promoted dandelion.

\section{Methods}

The study site was located in Denali National Park and Preserve within the developed zone near the park entrance. Disturbance history, soil texture, and dandelion seed input were similar throughout the study site, but distribution of dandelion varied considerably. The study site was disturbed by road and airport construction from 1988 to 1991 . The surrounding area had a large population of dandelion, and seed input to the study site was abundant. The study site was revegetated in 1991, and had not been redisturbed by further construction (Densmore et al. 2000). Most of the study site had been seeded with a mix of native legumes (Oxytropis campestris (L.) DC. (Field Locoweed) and Hedysarum alpinum L. (Alpine Sweetvetch)) and wheatgrasses (Elymus spp.). Most of the study site had also been fertilized in 1991 with Osmocote, a slow release fertilizer with a formulation of $14 \%$ nitrogen $(\mathrm{N}), 14 \%$ phosphorous $(\mathrm{P})$, and $14 \% \mathrm{~K}$, at a specified rate of $500 \mathrm{~kg} \mathrm{ha}^{-1}$. However, there were no records of how much fertilizer was actually applied; some spots were not fertilized and other spots were refertilized in subsequent years, thus increasing nutrient variation in otherwise similar soils. The study site included road cut and fill slopes that varied in slope and aspect, as well as more level disturbed areas.

In 2002, plots were established at 18 randomly selected sites. Slope and aspect were homogeneous within each sample site. The plots were $0.5 \mathrm{~m}$ wide, and varied in length from $2.5 \mathrm{~m}$ to $8 \mathrm{~m}$, depending on the size of the site. Percentage cover of vascular plants by species and surface ground cover were measured with a line transect along one edge of the plot. Surface ground cover was estimated using non-overlapping categories of nonvascular plants, litter, and bare ground (soil and 
TABLE 1 . Summary of study plot variables.

\begin{tabular}{lllc}
\hline \hline \multicolumn{2}{c}{ Mean (SE) } & Range \\
\hline $\begin{array}{l}\text { Dandelion cover (\%) } \\
\text { Dandelion density }\end{array}$ & 15.3 & $(4.3)$ & $0.0-22.5$ \\
$\quad$ (plants $\left./ \mathrm{m}^{2}\right)$ & 30.6 & $(8.6)$ & $0.0-114.0$ \\
Equivalent latitude $\left.{ }^{\mathrm{o}} \mathrm{N}\right)$ & 65.6 & $(2.1)$ & $52.5-79.7$ \\
Soil & & & \\
$\quad$ Total N (\%) & 0.08 & $(0.01)$ & $0.03-0.15$ \\
$\quad$ Available P (ppm) & 6 & $(1)$ & $1-12$ \\
Available K (ppm) & 51 & $(4)$ & $29-89$ \\
\hline \hline
\end{tabular}

${ }^{a}$ Equation 1.

gravel) to equal $100 \%$ cover. Density of dandelion plants was measured within the whole plot. Some plants of the native subspecies, Taraxacum officinale ssp. ceratophorum, were present and were excluded from the measures of dandelion cover and density. The native subspecies was readily distinguished by the presence of conspicuous horns on floral bracts. Dandelion voucher specimens were deposited at the University of Alaska herbarium. Slope and aspect of each plot were measured. A soil sample was taken adjacent to the midpoint of each plot in August 2002. Each sample was the contents of a hole $15 \mathrm{~cm}$ in depth and diameter. The soil fraction (particle size $<2.0 \mathrm{~mm}$ ) was analyzed for total $\mathrm{N}$, available $\mathrm{P}$, and available $\mathrm{K}$. Nitrogen content was determined by Kjeldahl analysis (Bremner and Mulvaney 1982). Extractable P was measured with the Olsen (Olsen and Sommers 1982) or Mehlich III method (Tran and Simard 1993), depending on $\mathrm{pH}$. Extractable $\mathrm{K}$ was measured with the Mehlich III method, which is correlated with plant K uptake (Bates and Richards 1993). The University of Alaska Agricultural and Forestry Experiment Station did all soil analyses.

The Statistical Analysis System (SAS) was used for data analysis. Dependent variables were dandelion cover $(\%)$ and density (plants $\left./ \mathrm{m}^{2}\right)$. Independent variables were equivalent latitude, and soil total $\mathrm{N}(\%)$, available $\mathrm{P}(\mathrm{ppm})$, available $\mathrm{K}(\mathrm{ppm})$. For each transect, slope and aspect were used to calculate equivalent latitude, an estimate of potential insolation and an effective predictor of soil temperature in interior Alas- ka (Dingman and Koutz 1974). The potential insolation of a surface is the quantity of solar energy that a surface would receive in a specified time period. If a restricted area is considered over a specified time period, then the relative potential insolation between points depends only on inclination (slope) and azimuth (aspect). The concept of equivalent latitude as an index of potential insolation is based on the fact that every slope is parallel to a horizontal plane on the earth's surface, and receives the same potential isolation as that plane. The latitude of that plane is called the equivalent latitude, $\theta^{\prime}$, and it depends on the inclination, $k$, and azimuth, $h$, of the slope as follows:

$$
\theta^{\prime}=\sin ^{-1}(\sin k \cos h \cos \theta+\cos k \sin \theta)
$$

where $k$ is measured in degrees downward from the horizontal, $h$ is measured in degrees clockwise from North, and $\theta$ is the actual latitude of the area in degrees.

Relationships among dependent and independent variables were examined with scatter plots and Pearson correlation coefficients with results considered statistically significant at $P<0.05$. Multiple regression analyses were then used to determine the best model for predicting the variation in dandelion cover and density.

\section{Results and Discussion}

Dandelion cover and density varied considerably between plots, even though disturbance history and seed input were similar (Table 1). Dandelion cover ranged from 11 to $22 \%$ on $28 \%$ of the plots, $1-10 \%$ on $50 \%$ of the plots, to no dandelions on $22 \%$ of the plots. Dandelion density, measured as plants $\mathrm{m}^{-2}$, ranged from $51-114$ on $22 \%$ of the plots, $26-50$ on $22 \%$ of the plots, $1-25$ on $39 \%$ of the plots, to no dandelions on $17 \%$ of the plots. Other non-native species occurred in only $11 \%$ of plots, with low mean $( \pm$ SE) cover $(0.2$ $(0.2) \%)$.

Dandelion cover was significantly correlated with equivalent latitude, and with soil levels of available $\mathrm{K}$ and $\mathrm{P}$, while dandelion density was significantly correlated only with equivalent latitude and soil $\mathrm{K}$ (Table 2). All soil nutrient variables were correlated with each other. The sample size was relatively small $(n=18)$,

TABLE 2. Pearson correlation, $r$, matrix of dependent and independent variables on study plots. Correlations significant at a level of $P<0.05$ are listed in bold type. $n=18$.

\begin{tabular}{|c|c|c|c|c|c|}
\hline \multirow[b]{2}{*}{ Variable } & \multirow[b]{2}{*}{$\begin{array}{l}\text { Dandelion } \\
\text { cover }(\%)\end{array}$} & \multirow[b]{2}{*}{$\begin{array}{l}\text { Dandelion density } \\
\quad\left(\text { plants } / \mathrm{m}^{2}\right)\end{array}$} & \multirow[b]{2}{*}{$\begin{array}{c}\text { Equivalent } \\
\text { latitude }\left({ }^{\circ} \mathrm{N}\right)^{\mathrm{a}}\end{array}$} & \multicolumn{2}{|c|}{ Soil } \\
\hline & & & & $\begin{array}{c}\text { Total N } \\
(\%)\end{array}$ & $\begin{array}{l}\text { Available P } \\
\text { (ppm) }\end{array}$ \\
\hline$\overline{\text { Dandelion cover }}$ & 1.00 & & & & \\
\hline Dandelion density & 0.89 & 1.00 & & & \\
\hline Equivalent latitude & -0.66 & -0.73 & 1.00 & & \\
\hline \multicolumn{6}{|l|}{ Soil } \\
\hline Total N & 0.38 & 0.39 & -0.05 & 1.00 & \\
\hline Available P & 0.55 & 0.39 & -0.22 & 0.79 & 1.00 \\
\hline Available K (ppm) & 0.68 & 0.52 & -0.09 & 0.69 & 0.72 \\
\hline
\end{tabular}

${ }^{\mathrm{a}}$ Equation 1. 
but the multiple regression analyses demonstrated that equivalent latitude and soil $\mathrm{K}$ were the best predictors for variation in dandelion cover $\left(r^{2}=0.79, P<0.0001\right)$ and density $\left(r^{2}=0.73, P=0.0002\right)$. Our results agree with those of Tilman et al. (1999), who found that grass communities with higher $\mathrm{K}$ levels had more dandelions. They demonstrated that dandelion had a higher requirement for $\mathrm{K}$ than competing grasses, and hypothesized that high soil $\mathrm{K}$ levels tipped the competitive balance toward dandelion. In our study, however, higher soil K levels increased dandelion cover and density even though the cover of potentially competing species was relatively low and bare soil was available for dandelion colonization (Table 3). Therefore, adding fertilizer with $\mathrm{K}$ is likely to promote dandelion infestations even in areas with little or no competing vegetation. Soil levels of available $\mathrm{P}$ were also significantly correlated with dandelion cover, but the relationship with $\mathrm{K}$ was stronger. Because $\mathrm{K}$ and $\mathrm{P}$ levels were significantly correlated, our field data would have to be supplemented with controlled experiments to further define the role of these nutrients. The data we do have supports Tilman et al. (1999), who found that P also promoted dandelion, but was less important than $\mathrm{K}$. The range of soil total $\mathrm{N}$ in the study area did not affect dandelion cover or density.

Dandelion cover and density also increased with equivalent latitude. We consider this to be a response to soil temperature because equivalent latitude is based on slope and aspect, and has been shown to be a good predictor for soil temperature in interior Alaska. Other soil variables such as texture were similar among samples. Dandelion benefits from warmer soils for growth and for carbohydrate and $\mathrm{N}$ storage in its taproot (Cyr et al. 1990). Currently, in Alaska, dandelion extends north to $67.8^{\circ}$ latitude, and has recently expanded its elevational range to $1121 \mathrm{~m}$ along the roadside in Denali National Park and Preserve. Continued climate warming is likely to increase the cover of dandelion within its current range, and promote invasion of new areas. Monitoring and immediate eradication may protect National Park Service units and other wildlands that are not currently infested with dandelion.

\section{Acknowledgments}

This study was funded by the U. S. National Park Service and the U.S. Geological Survey Alaska Science Center.

\section{Literature Cited}

ACIA. 2005. Page 2 in Impacts of a Warming Arctic - Arctic Climate Impact Assessment. Cambridge University Press, Cambridge, UK. 144 pages.

AKEPIC [Alaska Exotic Plant Information Clearinghouse]. 2005. Invasive Plants of Alaska. Alaska Association of Conservation Districts Publication, Anchorage, Alaska. 294 pages.

Bates, T. E., and J. E. Richards. 1993. Available potassium. Pages 59-64 in Soil Sampling and Methods of Analysis. Edited by M. R. Carter. Lewis Publishers, Ann Arbor, Michigan.
TABLE 3. Vegetation and ground surface cover (\%) on study plots.

\begin{tabular}{lccc}
\hline \hline & \multicolumn{2}{c}{ Mean (SE) } & Range \\
\hline Vascular plant cover $^{\mathrm{b}}$ & 37.6 & $(4.4)$ & $7.5-89.0$ \\
Ground surface cover $^{\mathrm{c}}$ & & & \\
Nonvascular plant & 25.4 & $(6.2)$ & $7.0-50.0$ \\
Litter & 27.2 & $(7.2)$ & $1.0-64.0$ \\
Soil and gravel & 47.6 & $(5.7)$ & $0.0-91.0$ \\
\hline \hline
\end{tabular}

${ }^{\mathrm{a}} n=18$ plots.

b Vascular plants other than dandelion.

${ }^{\mathrm{c}}$ Nonoverlapping categories that total $100 \%$.

Bremner, J. M., and C. S. Mulvaney. 1982. Nitrogen-total. Pages 595-624 in Methods of Soil Analysis, Part 2, Chemical and Microbial Properties, Agronomy Monograph 9. Edited by A. L. Page, R. H. Miller, and D. R. Keeney. Agronomy Society of America, Madison, Wisconsin.

Cyr, D. R., J. D. Bewley, and E. B. Dumbroff. 1990. Seasonal dynamics of carbohydrate and nitrogenous components in the roots of perennial weeds. Plant, Cell and Environment 13: 359-365.

Densmore, R. V., M. E. Vander Meer, and N. G. Dunkle. 2000. Native plant revegetation manual for Denali National Park and Preserve. U.S. Geological Survey, Biological Resources Division, Information and Technology Report USGS/BRD/ITR-2000-0006.

Dingman, S. L., and F. R. Koutz. 1974. Relations among vegetation, permafrost, and potential insolation in central Alaska. Arctic and Alpine Research 6: 37-42.

Hultén, E. 1968. Flora of Alaska and Neighboring Territories. Stanford University Press, Stanford, California. 2008 pages.

Jorgenson, M. T., C. H. Racine, J. C. Walters, and T. E. Ostercamp. 2001. Permafrost degradation and ecological changes associated with a warming climate in central Alaska. Climate Change 48: 551-579.

McKee, P. C. 2004. Distribution and ecology of exotic plants in Wrangell-St. Elias National Park and Preserve, Alaska. M.Sc. thesis, University of Alaska, Fairbanks, Alaska. 70 pages.

Olson, S. R., and L. E. Sommers. 1982. Phosphorous. Pages 403-430 in Methods of Soil Analysis, Part 2, Chemical and Microbial Properties, Agronomy Monograph 9. Edited by A. L. Page, R. H. Miller, and D. R. Keeney. Agronomy Society of America, Madison, Wisconsin.

Royer, F., and R. Dickinson. 1999. Weeds of Canada and the northern United States. The University of Alberta Press, Edmonton, Alberta, Canada. 434 pages.

Stewart-Wade, S. M., S. Neumann, L. L. Collins, and G. J. Boland. 2001. The biology of Canadian weeds. 117. Taraxacum officinale G. H. Weber ex Wiggers. Canadian Journal of Plant Science 82: 825-853.

Tilman, E. A., D. Tilman, M. J. Crawley, and A. E. Johnston. 1999. Biological weed control via nutrient competition: K limitation of dandelions. Ecological Applications 9: 103-111.

Tran, T. S., and R. R. Simard. 1993. Mehlich III-extractable elements. Pages 43-49 in Soil Sampling and Methods of Analysis. Edited by M. R. Carter. Lewis Publishers, Ann Arbor, Michigan.

Received 13 June 2007

Accepted 13 November 2008 